
\title{
АНГЛИЦИЗМЫ В ИНТЕРНЕТ-РЕКЛАМЕ: ЗАСОРЕНИЕ ИЛИ ТРЕНД
}

\section{ANGLICISMS IN INTERNET-ADVERTISING: CLOGGING OR TRENDING}

\author{
M. Tsaturyan \\ A. Matevosyan
}

Summary: The article discusses the features of the use of anglicisms in the texts of internet advertising. The relevance of the proposed topic is due to the study of anglicisms, which has been a modern problem for many countries of the world for more than a half of a century. On the one hand, the process of borrowing is inevitable, but on the other hand, the cultural basis of the native language must be preserved.

Keywords: anglicisms, internet-advertising, fashion tributes, language clogging, manipulation.
Цатурян Марина Мартиросовна

Д.филол.н., профессор, Кубанский государственный университет (Краснодар) tsaturyan.mm@mail.ru

Матевосян Ареват Паруйровна

Соискатель, Кубанский государственный университет (Краснодар)

arevik.matevosyan.85@mail.ru

Аннотация: В статье рассматриваются особенности использования англицизмов в текстах интернет-рекламы. Актуальность предложенной темы обусловлена изучением англицизмов, которая является современной проблемой для многих стран мира уже более полувека. С одной стороны, процесс заимствования неизбежен, но с другой стороны, должна сохраняться культурная основа родного языка.

Ключевые слова: англицизмы, интернет-реклама, дань моде, засорение языка, манипуляция.

тается приобщиться к идеализированной американской культуре и стилю жизни, употребляя в речи англицизмы [Сумцова 2012: 247-250].

Влияние английского языка в интернет-рекламе заметно возросло, так как он используется во многих сферах нашей жизни. Интернет-реклама, которая тесно связана с языковыми изменениями и отражает основные тенденции развития языка, вобрала в себя большое количество англицизмов. Они быстро проникают в систему интернет-рекламы, и использование англоязычных элементов становится нормой в языке интернет-рекламы.

Во всех сферах общественной жизни возрастает значение интернет-рекламы. Она не только стимулирует покупателей к приобретению товаров, но и влияет на формирование их мировоззрения и эстетических представлений. Одной из особенностей интернет-рекламы является тесная связь с языковыми изменениями, отражающими новые тенденции в языке. В последнее время отличительной чертой интернет-рекламы, как мы уже говорили выше, является обилие заимствованных слов, например, в инстаграме мы читаем:

«Полушерстяное кромби Walesby в аутентичном дизайне - сочетание элегантности и традиций неформального гардероба, увековеченного наследием британских субкультур» (инстаграм от 29 августа 2018 года). Однобортное пальто с потайной застежкой от англ: crombie обычно шьется из толстой шерстяной ткани темного цвета, но после плавного перехода из мужского гардероба в женский, цветовая гамма становится нежнее. Не возбраняется даже ненавязчивый узор, точно пригодится тем, кто привык одеваться в классическом элегантном стиле. Блогер использует манипулятивную стратегию предло- 
жения, употребляя англицизм кромби, автор отдает дань моде, шагая в ноту со временем. Или, например:

«Стиль - это элегантность и внимание к деталям. Всё это сочетает в себе сумка тоут от Divalli» (инстаграм от 1 февраля 2021 года). Большая, вместительная сумка с двумя ручками от англ: tote - идеальный вариант на каждый день, особенно если выбрать тоут универсального цвета - черного, серого, коричневого. В тоут действительно умещается все, от портмоне до ноутбука. Блогер использует манипулятивную статегию похвалы, употребляя англицизм тоут, автор создает ощущение престижа и таким образом усиливает мотивацию к приобретению данного товара.

В интернет-рекламе можно увидеть множество неологизмов, полученных в результате слияния английских и русских слов. Такое явление часто встречается в рекламных кампаниях косметического бренда, например, мы встречаем:

«Говорим о бронзерах в сторис, заходите посмоmреть, пока они не исчезли. В наличии три самых классных бронзера. Весна - самое время начать им пользоваться (инстаграм от 27 февраля 2021 года). Пудра для оттенки лица от англ: bronzer - главный тренд летнего сезона, который создаёт безупречный натуральный оттенок. Блогер привлекает особое внимание читателей в силу новизны, употребляя тактику идентичности. Также можно увидеть, например:

«На видео новогодний макияж с глиттером «Платиновое золото». Акция распространяется на все глиттеры. Чтобы получить третий оттенок в подарок, нужно добавить в корзину 2 и указать название третьего в комментарии к заказу» (инстаграм от 7 января 2021 года). Блёстки от англ: glitter - обычно используют в качестве теней для век и наносят его на кремовую базу, он не может высветлить отдельные участки, а просто придает лицу блеск. Блогер употребляет тактику предложения. Насыщая рекламу современными иностранными словами, автор повышает спрос на товар. Рассмотрим ещё один пример интернет-рекламы:

«Светоотражающий консилер «Miracle Touch» скрывает тёмные круги под глазами, камуфлирует мелкие сосудистые сеточки и покраснения, маскирует усталости на личе» (инстаграм от 23 июля 2020 года). Тональный крем от англ: concealer - средство, которое содержит максимальное количество красящего пигмента. Благодаря своей плотной текстуре он может скрыть прыщики, синяки под глазами и покраснения. Словом, консилер справляется с тем, что обычным кремам не под силу. Блогер использует англицизм консилер, которое имеет особое звучание, чтобы привлечь внимание потребителей, употребляя манипулятивную стратегию контактирования.

Современный русский язык пестрит разнообразными заимствованиями, они проникают во все сферы речи, в том числе и в средства массовой информации, которые играют серьёзную роль в распространении информации. Сегодня главным источникам языкового материала служит интернет-реклама, выполняющее весьма существенную функцию в процессе распространения иноязычной лексики. В интернет-рекламе по-разному относятся к англицизмам. Одни считают, что это модно и популярно, другие - засорением языка и даже проявлением неуважения к нему, например, в твиттере можно встретить такую рекламу:

«Тренды трендами, а каждой технике свой клиент. На 2018 год мы только ждём объявленных новых трендов от мировых экспертов. Но мне что-то подсказывает, что они будут связаны с техникой «тигровый глаз», «блоранж», «кулшейдинг» и «стробинг», «балаяж». Так говорят Мэтры из столицы» (твит от 6 апреля 2018 года). Блоранж от англ: blorange - это техника окрашивания, при которой соединяются оранжевый пигмент и цвет блонд, тенденция от англ: trend, пользователь от англ: client, специалист от англ: expert, охлаждение от англ: coolshading, техника макияжа стробинг от англ: strobing. Актуальность колоритности англицизмов очевидна, блогер применяет в речи англицизмы, которые в большинстве случаев, без знания значения слова, ведут к возникновению агнонимов. Такое использование слов засоряет язык, ведёт к непониманию речи.

Чрезмерное употребление англицизмов снижает интерес к родному языку, русской литературе и культуре, а также снижению грамотности и языковой и общей культуры человека, например в инстаграме мы читаем:

«Продаю! Очень уникальная и крутая вещь! Кейп в красивую клетку. Можно носить самостоятельно, или поверх пальто, тренча» (инстаграм от 10 февраля 2021 года). Накидка от англ: саре, дождевой плащ от англ: trench. Использование заимствованных слов глобального распространения, блогер употребляет без крайней необходимости, лишь для того, чтобы выделяться и проявить свою оригинальность. При таком использовании, иностранные слова из источников обогащения языка, превращаются на средство его засорения.

В использовании иноязычных слов, как и во многом другом, не нужно впадать в крайности, а стоит соблюдать меру: если есть исконно русское название - стоит употреблять его, а если нет русскоязычного аналога тогда стоит отдавать предпочтение иностранным словам, ведь мы, таким образом, отдаляемся от использования собственных русских слов. Мы легко внедряем в свой лексикон новые понятия, определения, которые порой даже не можем объяснить. С одной стороны, употребляя заимствованные слова, мы обогащаем свою речь, можем общаться с другими странами и народами, но с другой стороны, лишаемся того богатства, той легкости, которые определяют неповторимость нашего языка. 
Молодежь чаще всего подвергается манипуляциям, они. Еще не обладают достаточным влиянием, чтобы диктовать языковые нормы, но наиболее активно усваивают новые слова и выражения. Именно поэтому молодые говорят не так, как старшие, а старшие считают, что это засорение языка. Англицизмы должны соответствовать требованиям: любое заимствование должно быть необходимо, без него нельзя обойтись в русском языке; иноязычное слово должно употребляться правильно и точно в том значении, которое оно имеет в языковом источнике; оно должно быть понятно тем, кто его употребляет.
Лексика английского происхождения в устных и письменных высказываниях стала фактом русского языка. Любой цивилизованный, культурный человек должен употреблять англицизмы, но там и тогда, когда это необходимо и уместно. «Берегите чистоту языка, как святыню! Никогда не употребляйте иностранных слов. Русский язык так богат и гибок, что нам нечего брать у тех, кто беднее нас» [Тургенев 1882: 333].

Давайте беречь свой родной русский язык, не засорять его ненужными словами. Русский язык богат и обладает всеми средствами для передачи любого значения.

\section{ЛИТЕРАТУРА}

1. Брейтер М.А. Англицизмы в русском языке: история и перспективы. М.: Изд. АО «Диалог-МГУ».1997.С. 156.

2. Дьяков, А.И. Причины интенсивного заимствования англицизмов в современном русском языке. Новосибирск. 2003.

3. Дедюхина А.Г. Понятийная сущность англоязычного заимствования в текстах рекламы // Вестник Адыгейского государственного университета: Майкоп. 2011.C.106-110.

4. И.С. Тургенев 1882. Русский язык. Соч., т. Х, С. 333.

5. Сумцова 0.В. Причины использования англицизмов в русском молодежном сленге // Молодой ученый.2012.С. 42-43.

6. Цыгулева А.Г. Англоязычные заимствования в тексте рекламы: анализ актуализации и особенности функционирования // Известия Российского государственного педагогического университета им. А.И. Герцена: Санкт-Петербург. - 2009.С.203-206.

7. Щерба, Л.В. Языковая система и речевая деятельность //Л.В. Щерба. Л. Наука, 1974.С. 60-66.

8. Ярцева В.Н. Лингвистический энциклопедический словарь М.Большая рос. Энцикл.2002.С. 9.

( Цатурян Марина Мартиросовна (tsaturyan.mm@mail.ru), Матевосян Ареват Паруйровна (arevik.matevosyan.85@mail.ru). Журнал «Современная наука: актуальные проблемы теории и практики»

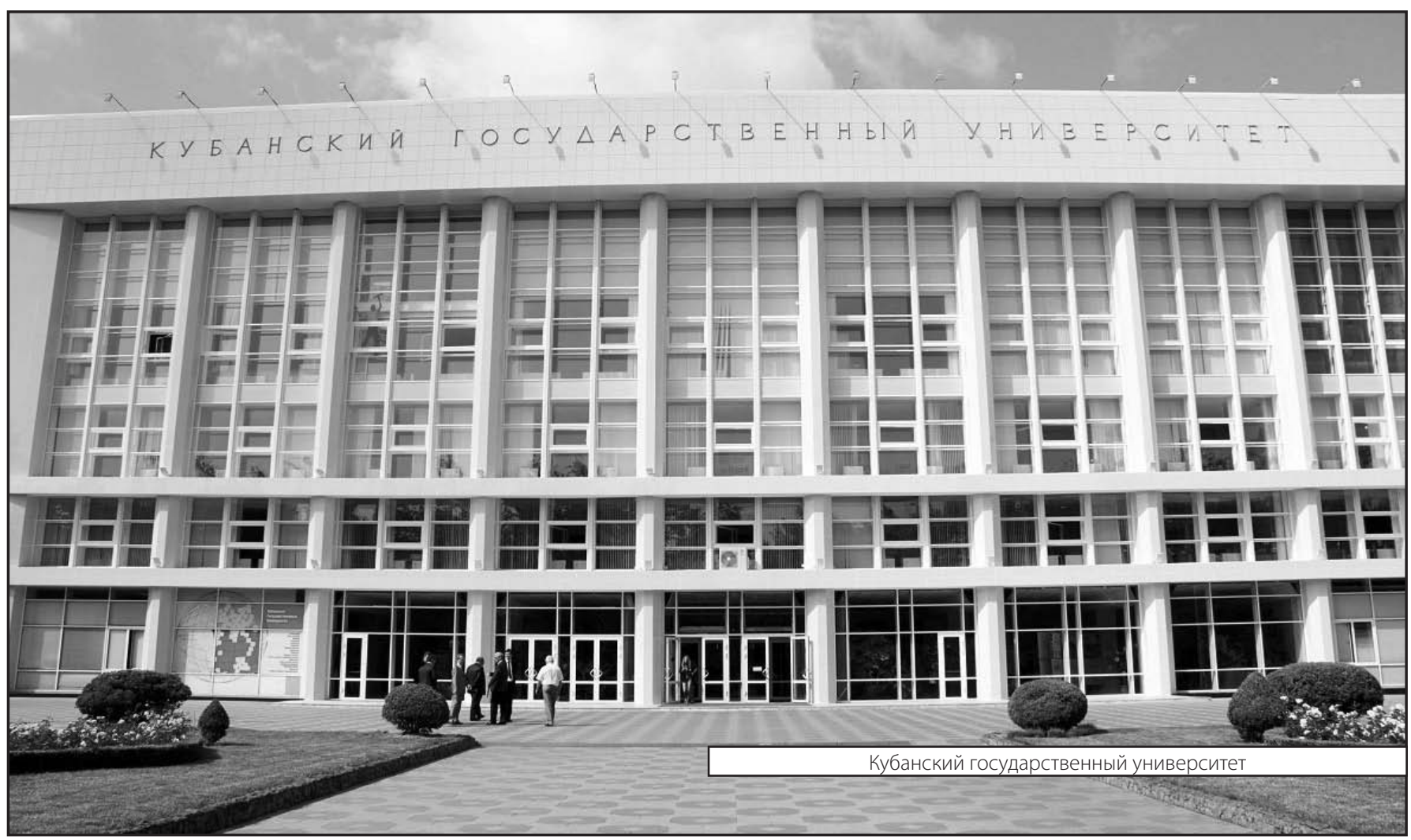

